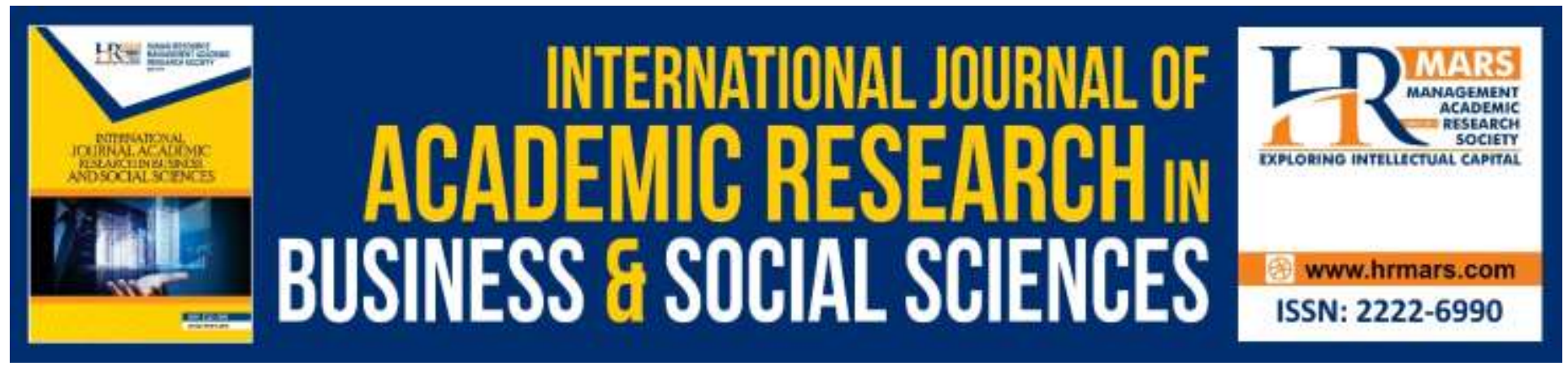

\title{
Errors in Reciting the Al-Quran during the Tilawah Al-Quran and Criteria for Evaluation
}

\author{
Najmiah Binti Omar, Nor Hafizi bin Yusof, Fatimah Zaharah Ismail, Wan \\ Fajrulhisyam Bin Wan Abdullah
}

To Link this Article: http://dx.doi.org/10.6007/IJARBSS/v9-i11/6598

DOI: 10.6007/IJARBSS/v9-i11/6598

Received: 10 October 2019, Revised: 30 October 2019, Accepted: 03 November 2019

Published Online: 13 November 2019

In-Text Citation: (Omar, Yusof, Ismail, Abdullah, 2019)

To Cite this Article: Omar, N. M., Yusof, N. H. B., Ismail, F. Z., Abdullah, W. F. B. W. (2019). Errors in Reciting the Al-Quran during the Tilawah Al-Quran and Criteria for Evaluation. International Journal of Academic Research in Business and Social Sciences, 9(11), 778-786.

Copyright: (C) 2019 The Author(s)

Published by Human Resource Management Academic Research Society (www.hrmars.com)

This article is published under the Creative Commons Attribution (CC BY 4.0) license. Anyone may reproduce, distribute, translate and create derivative works of this article (for both commercial and non-commercial purposes), subject to full attribution to the original publication and authors. The full terms of this license may be seen

at: http://creativecommons.org/licences/by/4.0/legalcode

Vol. 9, No. 11, 2019, Pg. 778 - 786

http://hrmars.com/index.php/pages/detail/IJARBSS

JOURNAL HOMEPAGE

Full Terms \& Conditions of access and use can be found at http://hrmars.com/index.php/pages/detail/publication-ethics 


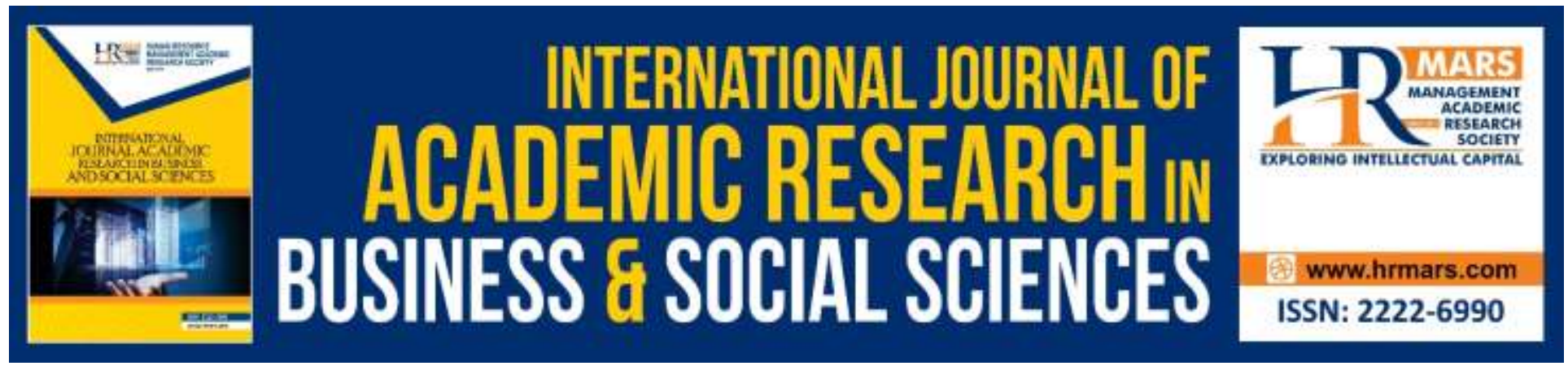

\title{
Errors in Reciting the Al-Quran during the Tilawah Al-Quran and Criteria for Evaluation
}

\author{
Najmiah Binti Omar, Nor Hafizi bin Yusof, Fatimah Zaharah \\ Ismail, Wan Fajrulhisyam Bin Wan Abdullah \\ Faculty of Islamic Contemporary Studies, Universiti Sultan Zainal Abidin, MALAYSIA
}

\begin{abstract}
Generally, errors that emerge during the Tilawah al-Quran can be divided into two, namely Jaliyy or explicit errors and Khafiyy or ambiguous errors. Both these errors can impair the recital, reduce the impeccability of the recital and create a lack of order in the recital, which then leads to the reduction in marks earned at the Tilawah al-Quran. Errors in reciting the al-Quran involve the fasahah, vocals, tarannum, and tajwid aspects. Hence, an immaculate recital of the al-Quran is a recital that lacks errors in the characteristics mentioned above. Thus, identifying these errors can form a guideline, especially for the qari and qariah who will be reciting the al-Quran.
\end{abstract}

Keywords: Reciting, Al-Quran, Tilawah, Development, Errors

\section{Introduction}

In the field of tajwid, there are two types of errors when reciting the al-Quran, namely 'Lahn Jaliyy' and 'Lahn Khafiyy'. Lahn Jaliyy is a major error, while Lahn khafiyy is a minor error. The Jaliyy error is committed by the reciter and his intentional act makes the recital a prohibited practice, such as changing the characters that are recited and changing the sentences or harakat due to carelessness of the reciter. Whereas the Lahn Khafiyy is a minor error, such as not completing the long method or not stopping the 'ghunnah' droning or humming as required. However, although this is a minor error, it blemishes the beauty of the al-Quran from the aspect of its recital due to the reciter's negligence. Hence, by learning tahsin (improving or enhancing the recital) al-Quran, each reciter can help develop the concern for identifying these errors and avoiding it.

An article by Salihin (2016) entitled "Kesalahan Jali Dalam Kalangan Peserta Majlis Tilawah al-Quran Peringkat Kebangsaan Ke-59 Tahun 2016", had elaborated about two errors found when reciting the al-Quran, which was Jaliy and Khafiy errors. Error in reciting the alQuran, which in Arabic is called al-lahn, is an error that occurs to the i'rab and leads to incorrect 
grammar; whereas regarding tajwid, al-lahn is an error in reciting and deviates from the correct recital.

This article also contains examples of Jaliy and Khafiy errors. Regarding the Jaliy errors, whether it causes changes to the meaning or not, it is still considered a grave error that could lead to a sin befalling the reciter of the al-Quran if the reciter is capable of learning. Khafiy errors are committed by the reciter regarding the rules that govern tajwid, such as omitting a ghunnah, mad or idgham.

These errors are categorised into several levels according to its severity. For example, the minor error regarding tajwid, such as reducing the degree of ghunnah, which is the droning or humming as well as reducing its length. The decree regarding this error is makruh and there are some 'weak' opinions that claim this error to be haram because it jeopardises the authenticity of the recital. Khafiy errors are divided into two levels. First, if the error dismisses an existing decree, then committing the error is haram. Second, if the error only dismisses a minor decree, then the error is considered makruh compared to a Jaliy error, whereby the error is considered haram based on qat'i.

\section{Errors in Tahsin al-Quran among the Qari}

Errors in recitals during the Tilawah al-Quran can blemish the event in general. Besides, based on participants' records there were qari and qariah who repeatedly committed errors when reciting the al-Quran during the Tilawah al-Quran (MAIDAM, 2014; Salim \& Mansor, 2018). These errors can result in the deduction of marks during the Tilawah al-Quran (MTQ). The Chairperson of the Panel of Judges, Dato' Haji Othman bin Mustapha, stated during the closing of the Tilawah alQuran 2015 that there were errors in the recitals by the qari and qariah related to tajwid and fasohah, such as changing the lines or characters. In addition, participants could not differentiate the pronunciation of a certain character (thickness and thinness), isti'la or istifal (Salihin, 2016:467).

Besides that, Zailani (2015) quoted from a speech by Zainal Abidin Ahmad, an Exco Member in the Selangor State Government that Almost $60 \%$ of Muslim students cannot read the al-Quran. This shows a weakness in reading the al-Quran that is frequently mentioned by teachers and researchers in the field of Islamic education. Muhammad Azhar found that the types of errors were errors related to the implementation of the makhraj and the characteristics of alphabets, such as errors in droning or humming or the lack of such an action, a pronounced or shallow recital, long or short recitals, incorrect recital of verses or alphabets and errors in stopping or beginning to recite a verse.

According to previous studies, literature in the form of books had not focused on errors in reciting the al-Quran. Moreover, studies had only revolved around the biodata of the qari or qariah and their success during the competition. Similarly, a review of previous literature had shown a lack of detail concerning these errors. Data were in the form of documentation that needed further studies and analysis to be of any use to society. Latest studies had examined 
errors in recitals that only focused on IPT students. Studies related to the Tilawah al-Quran (MTQ) were conducted in 2016 but only touched on the tajwid and fasahah aspects and did not discuss the vocal and tarannum aspects. Therefore, this study intended to focus on four main aspects, namely the latest tajwid, fasohah, vocals and tarannum because it involves qari dan qariah taking part in the Tilawah al-Quran 2019.

\section{Types of Errors when reciting the al-Quran by IPTA Students}

Zailani (2016); lacob. (2018) had discussed different types of errors when reciting the al-Quran by students from an IPTA in Malaysia. The study found that among the types of errors most frequently committed by students were:

\section{Types of Errors when Pronouncing the Makhraj Dan Characters}

Errors in pronouncing the Hijaiyah characters as well as errors in the characteristics of Hams or Jahr. Syiddah, tawassut and rakhawah, itbaq, or infitah, qalqalah, sofir, istitolah, inhiraf, Lin, ghunnah and khafa'.

\section{Types of Errors in Pronouncing with a Drone or Without a Drone}

Among the types of errors usually committed are to Ikhfa' the Nun at Ikhfa' Haqiqi, not droning Nun (sabdu) with two harakat, not droning Ikhfa' Haqiqi with two harakat, not consistent in conforming to the rules regarding droning, not droning mim (sabdu) with two harakat, thinning the droning when Nun meets the isti'la', droning when droning is not required, not to Ikhfa' the mim at the Ikhfa' syafawi, not droning idhgam ma'al ghunnah with two harakat, not droning Ikhfa' syafawi with two harakat, not combining the vocals at idgham ma'al ghunnah, thickening the droning when Nun meets istifal, not to Ikhfa' the mim at Iqlab (Ikhfa' Majazi), not droning Iqlab with two harakat, droning more than two harakat and not combining the vocals at Idgham bi la ghunnah.

\section{Types of Errors Concerning the Thick and thin Pronunciations (tarqiq/Tafkhim)}

These errors refer to thickening the istifal character, thinning the isti'la' character, thickening the pronunciation of a thin ro', thinning the pronunciation of a thick ro' and thinning a thick Lam jalalah.

\section{Types of Errors in long and Short Recitals}

Among the types of errors are extending beyond the normal rate, extending the character that should be long, the Mad Lazim Kalimi Muthaqqal is not extended to 6 harakat, not all the mad are of equal length, the Mad Munfasil is not 4 or 5 harakat, reducing the length of the character that should be actually long, Mad Lazim Harfi Mukhaffaf is not extended to 6 harakat, Mad Asli is not extended to 2 harakat, Mad Silah Kubra is not extended to 4 or 5 harakat, Mad Asli Harfi is not extended to 2 harakat, Mad Lazim Harfi Muthaqqal is not extended to 6 harakat, and Mad Badal is not extended to 2 harakat. 


\section{Types of Errors Related to Characters and Sentences when Reciting the Al-Quran}

Among the errors are those related to fathah, kasrah, dhommah, sukun and sabdu (diacritics) as well as errors related to reducing, adding or changing characters.

\section{Types of Errors Committed when Stopping or Beginning a Recital (Waqf/ Ibtida')}

Errors of this kind include stopping or repeating a recital when inhaling, starting a recital with a word that disrupts the language structure, stopping at a word that disrupts the structure of the grammar, stopping at a word that disrupts the actual meaning, stopping at the lining up of the last character and beginning a recital from the word that disrupts the actual meaning.

\section{The Method for Judging the National Tilawah Al-Quran (MTQ)}

The rules for the National Level Tilawah al-Quran stipulates the criteria for allocating marks during the judging of the Tilawah al-Quran, which involves four aspects:

\begin{tabular}{|c|r|l|}
\hline NUM. & FIELD & MARKS \\
\hline 1. & Tajwid & 40 \\
\hline 2. & Tarannum & 25 \\
\hline 3. & Fasohah & 20 \\
\hline 4. & Suara & 15 \\
\hline
\end{tabular}

Source: Jakim, 2009

There are several important elements that should be considered when judging fasohah, such as cautiousness and proficiency in reciting, the skill in uttering the kalimah and verses, all the characters, harakat (rows) and tashdid are given due attention, adherence to the waqf and ibtida' methods (including waqf jibril and waqf nabawi), recitals according to classical Arabic dialect (lahjah Arab fusha), recitals at a moderate speed (not too fast or too slow) and not to have a mix between tartil and tadwir recitals. Special characteristics of a recital in the field of fasohah involve recitals in the Arab dialect (lahjah), completion of a long verse in one breath and recitals that should be carefully thought over (tadabbur).

Besides that, elements that can undermine the recital leading to the deduction of marks in the fields of tajwid and fasohah are errors that occur at the beginning of a recital or a stipulated verse, ending a recital with more than 30 seconds left of the allotted time, not reciting the stipulated verses or surah as well as repeating prominent errors (Jaliy) and lacking continuous proficiency; hence, marks for fasohah will be cancelled or no marks will be given (Regulations for the National-level Tilawah al-Quran, 2011). 


\section{The Method for Deducting Marks When Judging}

Omar (2017) had mentioned the criteria for deducting marks when judging based on vocal and tarannum aspects. The voice plays an important role in Tilawah al-Quran. Among the categories of a good voice are as follows:

\begin{tabular}{|c|l|l|l|}
\hline Num. & $\begin{array}{l}\text { Category of } \\
\text { a Voice }\end{array}$ & Characteristics of the Voice & Level of the Voice \\
\hline 1 & Excellent & $\begin{array}{l}\text { Consistent tone, high, low, hoarse, soft, } \\
\text { sweet, smooth, clear, loud, clean and } \\
\text { sharp. }\end{array}$ & $\begin{array}{l}\text { A special voice and } \\
\text { easy to learn }\end{array}$ \\
\hline 2 & Good & $\begin{array}{l}\text { Consistent tone, moderate, low, hoarse, } \\
\text { soft, sweet, smooth, clear, loud and sharp. }\end{array}$ & $\begin{array}{l}\text { A special voice and } \\
\text { easy to learn }\end{array}$ \\
\hline 3 & Fair & $\begin{array}{l}\text { Consistent tone, high, small, soft, sweet, } \\
\text { smooth, clear, clean and sharp. }\end{array}$ & $\begin{array}{l}\text { A special voice and } \\
\text { easy to learn }\end{array}$ \\
\hline 4 & Poor & $\begin{array}{l}\text { Out-of-tune, thin, weak, hard, hoarse, } \\
\text { breaking up, shivering, drowning, choking. }\end{array}$ & $\begin{array}{l}\text { A problematic voice } \\
\text { that needs } \\
\text { improvement and } \\
\text { modification in the } \\
\text { long term. }\end{array}$ \\
\hline
\end{tabular}

Source: Omar (2017)

The criteria for deducting marks (voice) when judging the Tilawah al-Quran are as follows:

Criteria for Deducting Marks (voice)

\begin{tabular}{|l|l|l|l|}
\hline Field & Num. & Type of Voice & Reduction in Marks \\
\hline \multirow{4}{*}{ Voice } & 1 & A hoarse voice. & Deduction of one mark \\
\cline { 2 - 4 } & 2 & $\begin{array}{l}\text { An out-of-tune voice that disrupts the } \\
\text { recitation }\end{array}$ & Deduction of one mark \\
\cline { 2 - 4 } & 3 & Drowning voice & Deduction of one mark \\
\cline { 2 - 4 } & 4 & A breaking-up voice & Deduction of one mark \\
\cline { 2 - 4 } & 5 & A choking voice & Deduction of one mark \\
\cline { 2 - 4 } & 6 & $\begin{array}{l}\text { A shivering voice due to a very high or low } \\
\text { pitch }\end{array}$ & Deduction of one mark \\
\cline { 2 - 4 } & 7 & A voice that lacks three tabaqat & Deduction of one mark \\
\cline { 2 - 4 } & 9 & A stiff voice & Deduction of one mark \\
\cline { 2 - 4 } & 10 & A voice that shifts in quality & Deduction of one mark \\
\cline { 2 - 4 } & 11 & $\begin{array}{l}\text { Does not carry an ikhtilal al-lahn for one } \\
\text { recital }\end{array}$ & Deduction of one mark \\
\cline { 2 - 4 } & 12 & If the same errors are repeated & $\begin{array}{l}\text { Marks are deducted with a rate of not } \\
\text { more than five }\end{array}$ \\
\hline
\end{tabular}

Source: Omar (2017) 
INTERNATIONAL JOURNAL OF ACADEMIC RESEARCH IN BUSINESS AND SOCIAL SCIENCES

Vol. 9, No. 11, November, 2019, E-ISSN: 2222-6990 @ 2019 HRMARS

\section{Criteria for Deducting marks in the Field of Tarannum}

\begin{tabular}{|c|c|c|c|}
\hline Field & Num. & Error & Deduction of Marks \\
\hline \multirow{10}{*}{ Tarannum } & 1 & $\begin{array}{l}\text { Recitals with less than four types of } \\
\text { tarannum }\end{array}$ & $\begin{array}{l}\text { Four marks are } \\
\text { deducted for omitting } \\
\text { each mandatory } \\
\text { tarannum }\end{array}$ \\
\hline & 2 & $\begin{array}{l}\text { Not reciting two types of tarannum that } \\
\text { have been stipulated }\end{array}$ & $\begin{array}{l}\text { Four marks are } \\
\text { deducted for omitting } \\
\text { one of two tarannum }\end{array}$ \\
\hline & 3 & $\begin{array}{l}\text { Reciting less than four harakat for each } \\
\text { tarannum }\end{array}$ & $\begin{array}{l}\text { One mark is deducted } \\
\text { for one less harakat. }\end{array}$ \\
\hline & 4 & $\begin{array}{l}\text { Not carrying three tabaqat for each } \\
\text { tarannum }\end{array}$ & $\begin{array}{l}\text { One mark is deducted } \\
\text { for each tabaqat that } \\
\text { is not carried }\end{array}$ \\
\hline & 5 & Takrir at the tarannum & $\begin{array}{l}\text { One mark is deducted } \\
\text { for one error. }\end{array}$ \\
\hline & 6 & Takrir at the harakat & $\begin{array}{l}\text { One mark is deducted } \\
\text { for one error }\end{array}$ \\
\hline & 7 & Wholly copying the recital of a famous qari & $\begin{array}{l}\text { Deduction of one } \\
\text { mark. }\end{array}$ \\
\hline & 8 & $\begin{array}{l}\text { Not carrying a wuslah al-mumathalah and } \\
\text { ikhtilal al-lahn for each recital }\end{array}$ & $\begin{array}{l}\text { Deduction of one } \\
\text { mark. }\end{array}$ \\
\hline & 9 & $\begin{array}{l}\text { The closing tarannum is not similar to the } \\
\text { opening tarannum }\end{array}$ & $\begin{array}{l}\text { Deduction of one } \\
\text { mark. }\end{array}$ \\
\hline & 10 & \multicolumn{2}{|c|}{$\begin{array}{l}\text { If the errors are similar and repeated, marks should be deducted at a } \\
\text { rate of not more than five }\end{array}$} \\
\hline
\end{tabular}

Source: Omar (2017) 


\section{Criteria for Deducting marks in the Field of Fasohah}

\begin{tabular}{|c|c|c|c|}
\hline Field & Num. & Error & Deduction of Marks \\
\hline \multirow{6}{*}{ Fasahah } & 1 & $\begin{array}{l}\text { Error when beginning a stipulated } \\
\text { recital or verse }\end{array}$ & Deduction of one mark \\
\hline & 2 & $\begin{array}{l}\text { Ending the recital with more than } \\
30 \text { seconds left of the allotted time }\end{array}$ & Deduction of one mark \\
\hline & 3 & $\begin{array}{l}\text { Omitting or skipping a verse during } \\
\text { the recital }\end{array}$ & Deduction of one mark \\
\hline & 4 & $\begin{array}{l}\text { Not reciting a stipulated verse or } \\
\text { surah }\end{array}$ & $\begin{array}{l}\text { The recital is rejected, or no } \\
\text { marks are given }\end{array}$ \\
\hline & 5 & If a similar error is repeated & $\begin{array}{l}\text { Marks can be deducted with a } \\
\text { rate of not more than five } \\
\text { marks }\end{array}$ \\
\hline & 6 & $\begin{array}{l}\text { If the jaliy errors are repeated or } \\
\text { there is no continuous consistency }\end{array}$ & $\begin{array}{l}\text { Marks for fasahah are } \\
\text { cancelled or no marks are } \\
\text { given. }\end{array}$ \\
\hline
\end{tabular}

Source: The PhD thesis by Najmiah binti Omar, 2017

\section{Conclusion}

A recital of the holy verses of the al-Quran that is of good quality is a recital that does not contain too many errors. Hence, the qari and qariah should be cautious when reciting the al-Quran in order to avoid errors as this would influence the allocation as well as deduction of any marks. Thus, by possessing knowledge about the characteristics of the criteria mentioned in this article, it would at least serve a guideline and help the qari and qariah when reciting the al-Quran.

All four aspects, such as vocals, tajwid, fasahah and tarannum should be given due attention in order to avoid too many errors when reciting the al-Quran. Continuous and consistent training as well as guidance by a well-trained teacher could contribute towards a recital that is well-established and of good quality.

Contributors/Acknowledgement: All authors contributed equally to the conception and design of the study. We express our deepest gratitude to Center for Research Excellence \& Incubation Management (CREIM) and Faculty of Islamic Contemporary Studies, Universiti Sultan Zainal Abidin for supporting our intellectual endeavor.

\section{References}

Ahmad, M. Y. (2015). Sejarah Dan Kaedah Pendidikan al-Quran. Cet. Ke-4. Kuala Lumpur: Universiti Malaya. 
lacob, S..V. (2018). The Spectral Analysis of Labor Force and Profit of Construction Materials Distribution Companies in Romania Analogue Spectrum of Light in Physics, International Journal of Academic Research in Accounting, Finance and Management Sciences 8 (3): 5362.

Omar, N. (2017). Pengajian Tarannum Al-Quran Di Terengganu Dari Tahun 1960-2013: Kajian Terhadap Metodologi Pengajaran Rogayah Binti Sulong. 2017. Kuala Lumpur: Universiti Malaya (the unpublished thesis).

Razall, A. S. M. (2016). Implikasi Ketokohan Qari-qari Tanah Melayu Terhadap Kewujudan Program Tarannum Di Malysia: Satu Tinjauan. Jurnal Pendidikan Bil 1 (2) 2014. 5-13.

Saari, M. (2007). Johan Qari dan Qariah Malaysia, Kuala Lumpur: JAKIM.

Saari, M. (2008). 50 Tahun Tilawah al-Quran Malaysia, Putrajaya: JAKIM.

Salim, N. R., \& Mansor, I. (2018). Training and Teaching of Arabic Translation Course in IPG: Perspectives of Trainees and Trainers. International Journal of Academic Research in Progressive Education and Development, 7(4), 364-375 